\title{
Собственные имена у этнических тувинцев Монголии
}
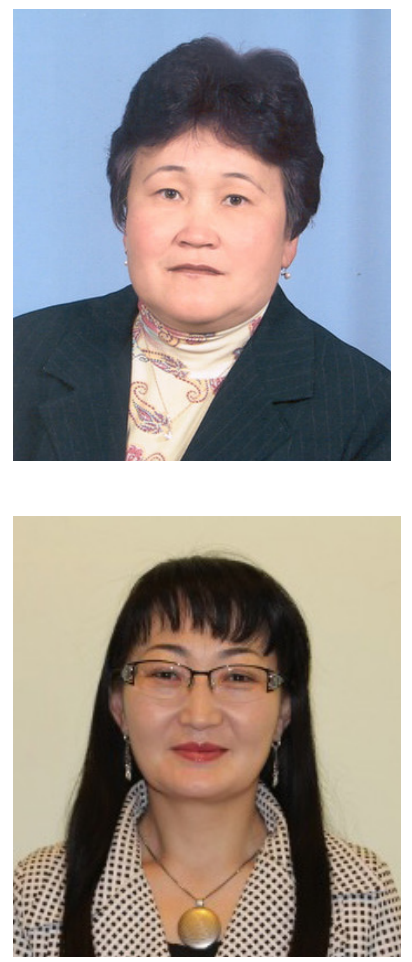

Надежда Д. Сувандии, Цецегдарь Уламсурэн

Тувинский государственный университет, Российская Федерация
В статье рассматривается использование собственных имен тувинцев, которые проживают в сумонах Цэнгэл Баян-Улэгэйского, Буянт Ховдского, Цагаан-Нуур Хубсугульского аймаков Монголии. Материалом исследования послужили собственные имена, собранные авторами во времена комплексных научных экспедиций в 1999-2019 г2. на территории Ховдского, Баян-Улэгэйского и Хубсугульского аймаков Монголии.

В исследуемых территориях исконно тувинские собственные имена в настоящее время стали малоупотребительными, иногда и редко употребительными. Основной причиной данного явления является то, что носителей родного тувинского языка становится все меньше, т. к. старшее поколение сменяется новыми, которые пользуются языком местного населения - монгольским, считая его родным. Сравнительный анализ между территориями все же показал различие: тувинцы сумона Цэнгэл Баян-Улэгэйского аймака Монголии сохранили больще и тувинских собственных имен, и больше в целом говорят на тувинском языке.

Ключевые слова: тувинский язык; ономастика; собственное имя; личное имя; тувинское имя; тувинцы; антропоним; топоним; зооним; сумон; аймак; Тува; Монголия

Работа выполнена при финансовой поддержке РФФИ в рамках научного проекта № 19-012-00073 «Трансформационные процессы в ономастике народов Центральной Азии: история и современность (на примере Тувы, Тофаларии, Калмыкии и Монголии».

\section{Для цитирования:}

Сувандии Н. Д., Уламсурен Ц. Собственные имена у этнических тувинцев Монголии // Новые исследования Тувы. 2020, № 4. C. 156-168. DOI: www.doi.org/10.25178/nit.2020.4.11

Сувандии Надежда Дарыевна - кандидат филологических наук, декан филологического факультета Тувинского государственного университета. Адрес: 667004, Россия, г. Кызыл, ул. Педагогическая, д. 13. Тел.: +7 (923) 268-93-69. Эл. адрес: suvandiin@mail.ru

Уламсурэн Цэцэгдарь - кандидат филологических наук, старший преподаватель кафедры тувинской филологии и общего языкознания филологического факультета Тувинского государственного университета. Адрес: 667000, Россия, г. Кызыл, ул. Интернациональная, д. 20., кв. 11. Тел.: +7 (923) 386-85-18. Эл. адрес: uthetheg@yandex.ru

SUVANDII, Nadezhda Daryevna, Candidate of Philology, Dean, Philological Faculty, Tuvan State University. Postal address: 13 Pedagogicheskaya St., 667004 Kyzyl, Russian Federation. Tel.: +7 (923) 268-93-69. E-mail: suvandiin@ mail.ru

ORCID ID: 0000-0002-3817-2436

ULAMSUREN, Tsetsegdari, Candidate of Philology, Senior lecturer, Department of Tuvan Philology and General Linguistics, Philological Faculty, Tuvan State University. Postal address: 11-20 Internationalinaya St., 667000 Kyzyl, Russian Federation. Tel.: +7 (923) 386-85-18. E-mail: uthetheg@yandex.ru 


\title{
Personal names of ethnic Tuvans in Mongolia
}

\author{
Nadezhda D. Suvandii, Tsetsegdari Ulamsuren \\ Tuvan State University, Russian Federation
}

\begin{abstract}
The article considers the proper names of Tuvans living in sums Tsengel (Bayan-Ölgii aimag), Buyaet (Khovd aimag), TsagaanNuur (Khövsgöl aimag), Mongolia. Our study relies on sources collected during comprehensive research expeditions the author led in 1999-2019 on the territory of Khovd, Bayan- Ölgii and Khövsgöl aimags of Mongolia.

Throughout the studied territories, native Tuvan proper names have now become rare and little-used. The main reason for this is the decrease in the number of Tuvan language speakers, as the older generation is replaced by new ones who speak Mongolian and consider it their native language. A comparative analysis of the territories mentioned showed that the Tuvans of sum Tsengel (Bayan-Ölgii aimag) have preserved more Tuvan names and more frequently speak Tuvan language.
\end{abstract}

Keywords: Tuvan language; onomastics; proper name; personal name; Tuvan name; Tuvans; anthroponym; toponym; zoonym; sum; aimag; Tuva; Mongolia

The article was written with the support of RFBR as part of grant project No. 19-012-00073 "Transformative processes

in the onomastics of the languages of Central Asia: history and modernity in the cases of Tuva, Tofalaria, Kalmykia and Mongolia".

\section{For citation:}

Suvandii N. D. and Ulamsuren Ts. Sobstvennye imena u etnicheskikh tuvintsev Mongolii [Personal names of ethnic Tuvans in Mongolia]. New Research of Tuva, 2020, no. 4, pp. 156-168. (In Russ.). DOI: www.doi.org/10.25178/nit.2020.4.11

\section{Введение}

Собственные имена, называющие единичные предметы из ряда однородных (в отличие от нарицательных), входят в поле внимания ономастики и содержат значительный пласт исторического прошлого каждого этноса, его языка и культуры. Целью данной работы является анализ употребления собственных имен у тувинцев, проживающих за пределами Республики Тыва, а именно - в Ховдском, Цэнгэльском аймаках Западной Монголии, Хубсугульском -Северной Монголии. В этих территориях у тувиноязычного населения исконно тувинские собственные имена стали редко употребляться, что вызывает обеспокоенность ученых о том: ведь в дальнейшем они могут и вовсе исчезнуть из употребления.

Источником исследования послужили собственные имена (людей, животных, местностей), собранные авторами в научных экспедициях в 1999-2020 гг. на территории Ховдского, Баян-Улэгэйского аймаков Западной, Хубсугульского аймака Северной Монголии. 


\section{История изучения тувинских собственных имен}

В тувинском языкознании исследованием ономастики в разные годы занимались немало ученыхфилологов. Зачинателем изучения собственных имен здесь является Н. Ф. Катанов, видный ученыйтюрколог, внесший большой вклад в исследование тюркских языков. В 1889 г. он проводил научную экспедицию в Урянхайский край, результаты которого опубликовал в первой академической грамматике тувинского языка, где дал перечень тувинских некоторых топонимов и антропонимов (Катанов, 1903). Всестороннее изучение тувинской ономастики получило распространение в конце 60-х годов XX столетия, спустя почти более полувека после исследований Н. Катанова.

Из всех разделов ономастики тувинского языка на сегодня наиболее изученными считаются топонимы и антропонимы. К научным исследованиям 1960-х гг. по топонимической системе тувинского языка относятся работы первого тувинского доктора филологических наук, профессора Ш. Ч. Сата (Сат, 1969), известного лексиколога тувинского языка Б. И. Татаринцева (Татаринцев, 1973, 1977ab). С начала 1980-х годов исследованиями по тувинской топонимии вплотную стала заниматься Б. К. Ондар, которая опубликовала основные научные труды по географическим наименованиям, ставшие настольной книгой исследователей тувинской ономастики. К таковым относятся «Топонимический словарь тувинского языка» в двух выпусках (Ондар, 2004, 2007) и монографии (Ондар, 2008, 2011).

Вопросами исследования тувинской топонимической системы в настоящее время также интересуется немало ученых-филологов. Исследования последних лет были собраны и опубликованы в том числе в составе специального выпуска журнала «Новые исследования Тувы» № 32018 года ${ }^{1}$ и в других изданиях (Бавуу-Сюрюн, 2018; Бадарч, Бавуу-Сюрюн, 2018; Кара-оол, 2018, 2019ab; Сувандии, 2018, 2019а) и др.

По антропонимической системе тувинского языкознания исследования проводились исследователем-диалектологом 3. Б. Чадамба (Чадамбаа, 1965, 1993), известным этнографом С. И. Вайнштейном (Вайнштейн, 1969, 1989), автором данной статьи (Сувандии, 2011, 2012, 2016, 2019b, 2020).

Собственные названия (клички) животных, чаще всего домашних - собак, лошадей, коров, коз и др., составляют разряд зоонимов (Бондалетов, 2016: 7). В тувинском языке были попытки частичного изучения проблем зоономии тувинского языка в единичных научных работах автора данной статьи (Сувандии, Куулар, 2010), имеются некоторые работы ученых, затрагивающие отдельные стороны названий крупного рогатого скота, в частности, лошадей (Монгуш, Юлдашбаев, 2015). Следует отметить, что в тувинской ономастической системе вопрос исследования зоонимии остается одним из актуальных и неизученных и ждет своего дальнейшего всестороннего исследования в связи с тем, что тувинцы были потомственными животноводами и остаются ими по сегодняшний день.

\section{Собственные имена - антропонимы}

Основным занятием исследованных нами субэтнических групп тувинцев является животноводство. В сумоне Цэнгэл проживают около 3000, в сумоне Буянт - около 2000 этнических тувинцев. Цэнгэльские тувинцы по сравнению с ховдскими хорошо владеют родным тувинским языком, что было заметно при работе с информаторами во время научных экспедиций. В Ховдском аймаке родным тувинским языком владеет только некоторая часть взрослого населения, а молодежь в основном общается на монгольском. Повседневным языком их общения является монгольский, молодежь и дети с родителями общаются только на монгольском, на наши вопросы, хотя суть понимают, они отвечали по-монгольски, а родители нам переводили их ответы.

В сумоне Цагаан-Нуур Хубсугульского аймака Монголии проживает малочисленная группа этнических тувинцев, которые называют себя тухаларами, общей численностью около 300 человек. Официальным языком общения в сумоне является монгольский, но в повседневной жизни старшее и среднее поколение тухаларов, наравне с монгольским, пользуются и родным тувинским, а молодежь и дети - только монгольским.

В настоящее время язык, фольклор, этнография и культура этнических тувинцев сумона Цэнгэл Баян-Улэгэйского аймака исследована в работах Хийс Г. (Хийс, 2009), Бадарч Б. (Бадарч, 2009), сумона Буянт Кобдоского аймака - Уламсурэн Ц. (Уламсурэн, 2013). Язык, фольклор, этнография и культура этнических тувинцев сумона Цагаан-Нуур не были специальным объектом научных исследований.

${ }^{1}$ https://nit.tuva.asia/nit/issue/view/39 
Большая часть тухаларов, как и тувинцы сумонов Западной Монголии, ведет кочевой образ жизни, их традиционные занятия - оленеводство, охота и рыболовство. Тухаларов называют цаатанами по роду их деятельности цаа 'северный олень' (Монгольско-русский словарь, 1957: 598).

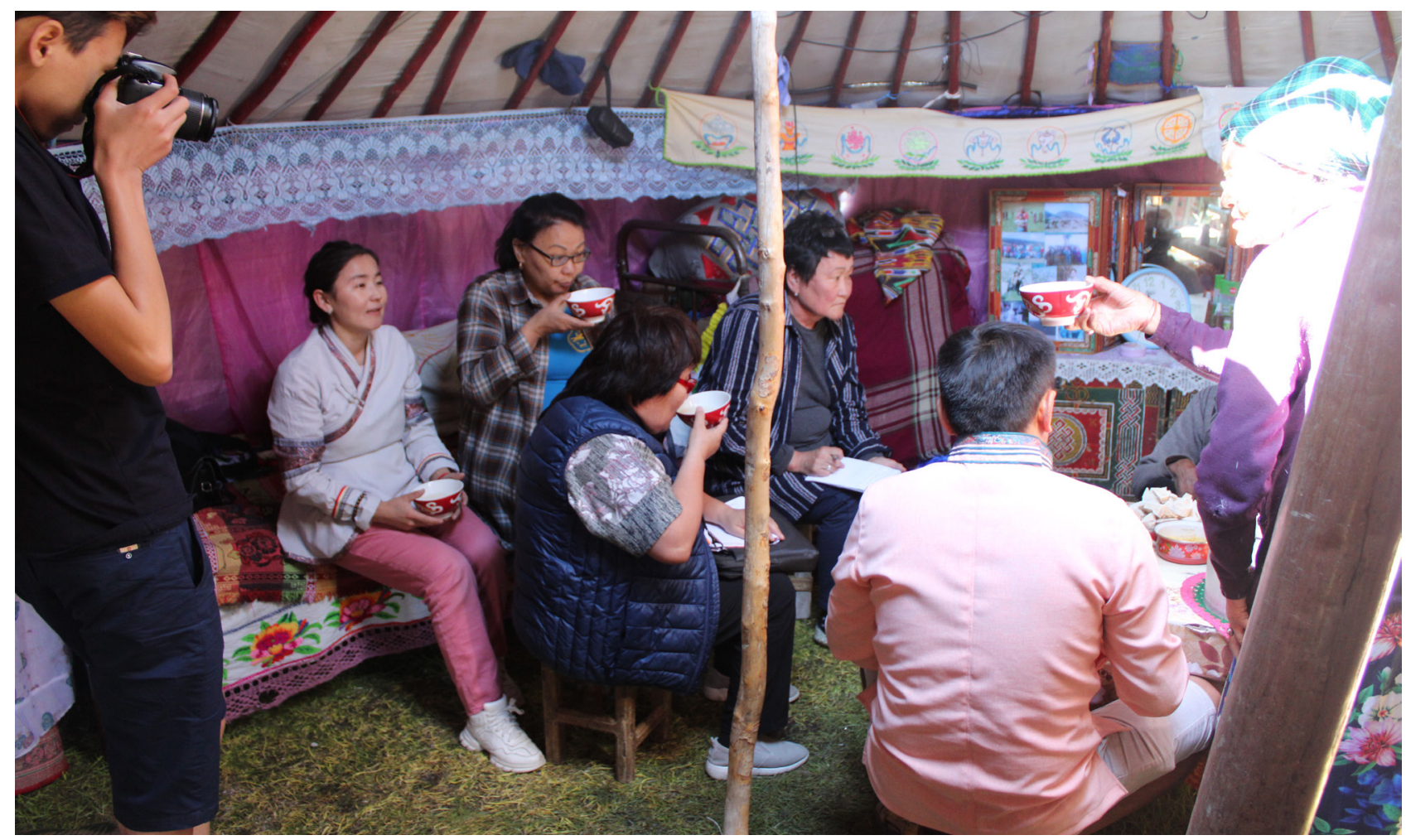

Фото 1. Работа с информаторами в местечке Харааты сумона Цэнгэл, Монголии в 2019 г. Фото из архива Н. Д. Сувандии. Photo 1. Working with respondents in the settlement of Kharaaty, sum Tsengel, Mongolia, 2019. Photo from the personal archive of N. D. Suvandii.

Антропонимов в речи цэнгэльских этнических тувинцев, которые называются кош аттар - 'парные имена' - также зафиксировано немало, причем официальными являются монгольские, а иногда бывают и казахские в зависимости от национальности отца. В настоящее время в сумоне Цэнгэл много смешанных браков именно с парнями казахами, которые составляют большую часть населения, и дети от этих браков в большей части берут себе имена казахского происхождения ${ }^{1}$.

Но и в таких семьях встречаются так называемые 'парные имена'. Если брать литературный тувинский язык, то это и есть прозвища, которые у тувинцев функционируют по обычаям издавна. К ним относятся имена, характеризующие внешние особенности носителя: Көгерген /м./ - от слова көк - 'синий', например, если ребенок при рождении задыхался и посинел, в связи с чем и получил данное имя; Бора-оол /м./ - от бора - 'серый' и оол 'мальчик' - у денотата имени при рождении было несколько сероватых волосинок; Борбаанды /ж./ - от борбак - 'круглый’, носитель имени с младшего возраста могла быть пухлой и родители ласкательно назвали таким 'парным именем’, Дөрбелчин /м./ от дөрбелчин - 'квадратный’, если парень с детства был сильным, здоровым, высоким² и др.

Встречаются 'парные имена', выражающие различные пожелания родителей: Күзел /ж./ - от слова күзел - 'желание, пожелание', это распространенное среди девочек имя в сумоне Цэнгэл, родители которых хотят светлого будущего своим дочерям, Бакыр /м./ - от слова баш - 'голова, с головой', когда денотат с детства имеет большую по размеру голову. По словам родителей, 'парное имя' дано сыну с пожеланием светлого будущего, чтобы, повзрослев, он стал «большим начальником». Шынар /ж./ - от шынар - 'качество, свойство, признак'. Такое имя много лет назад получила девочка, которая с детства была очень старательной, имела только положительные качества (имя было зафиксировано нами всего один раз, сейчас это женщина преклонных лет). Родители дали ей это имя, чтобы она всю жизнь

${ }^{1}$ Донгак-Хөйүк Долгар-Сурун, 67 л., род. в сумоне Цэнгэл Баян-Улэгэйского аймака Монголии.

${ }^{2}$ Шунгуур Иргит Чимеддорж, 69 л., род. в сумоне Цэнгэл Баян-Улэгэйского аймака Монголии. 
оставалась с этими качествами ${ }^{1}$. Другие примеры: Амар-Чыргал Амыр-Чыргал /м./ - от слов амыр ‘легкий, нетрудный’ и чыргал - ‘блаженство, благоденствие; счастье', данное имя родителями дано с пожеланием нетрудной счастливой жизни ребенку в будущем².

Зафиксировано парное имя, связанное с недостатком денотата: Аазатпай /м./ - от слова аазатпай 'разиня, ротозей, разгильдяй'. Родители умилительно дали данное 'парное имя' сыну, очень медлительному, даже в младенчестве который редко плакал, Доңху /м./ - от доңху возможно даңга (западный диалект тувинского языка) дүлей 'глухой’ - имя дано мальчику плохо слышащему (глухому) с детства ${ }^{3}$. Подобных имен нами больше не зафиксировано, отсюда сделать вывод, что родители очень осторожны при наречении с 'парными именами'.

Встречаются единичные 'парные имена', связанные различным обстоятельствами рождения ребенка: Чайлаг /м./ - от чайлаг - 'летнее стойбище', дано мальчику, родившемуся при перекочевке на летнюю стоянку, Ыңгаа /ж./, по словам информатора, образовано от подражательного слова ыңаа 'плач’ - ‘парное имя’ девочки, которая в младенчестве постоянно плакала и в подростковом возрасте также начинала сразу плакать, если ей говорили грубое слово.

Этнические тувинцы редко, но в качестве единичных 'парных’ употребляют и имена, связанные с названиями домашних животных и птиц: Бодаган /м./ - от бодаган - 'верблюжонок', имя мальчика, родители которого всю жизнь занимались разведением верблюдов; Авырган /м./ - от авырган - 'белкалетяга', имя подростка, отец которого всю жизнь занимался охотой.

Во время сбора материала мы зафиксировали личные имена тувинцев, которых этнические тувинцы Цэнгэла используют в качестве 'парных имен': Айдың /м./ - от айдың - ‘лунный', Шолбан /м./ - от шолбан - 'яркая звезда Венера', Аяс-оол /м./ - от слов аяс - 'ясный’ и оол - 'мальчик'; антропонимы, связанные с названиями явлений природы; Мөңгүн /м./ - от мөңгүн - 'серебро, серебряный', Алдын /м./, Алдын-Ай /м./ - от алдын - 'золото, золотой’ и ай - ‘луна', связанные с названиями минералов и драгоценных камней. Информаторы объясняют заимствования данных имен тем, что с конца 90-х гг. XX и начала XXI столетия тувинцы сумона Цэнгэл имеют хорошие связи с тувинским народом России.

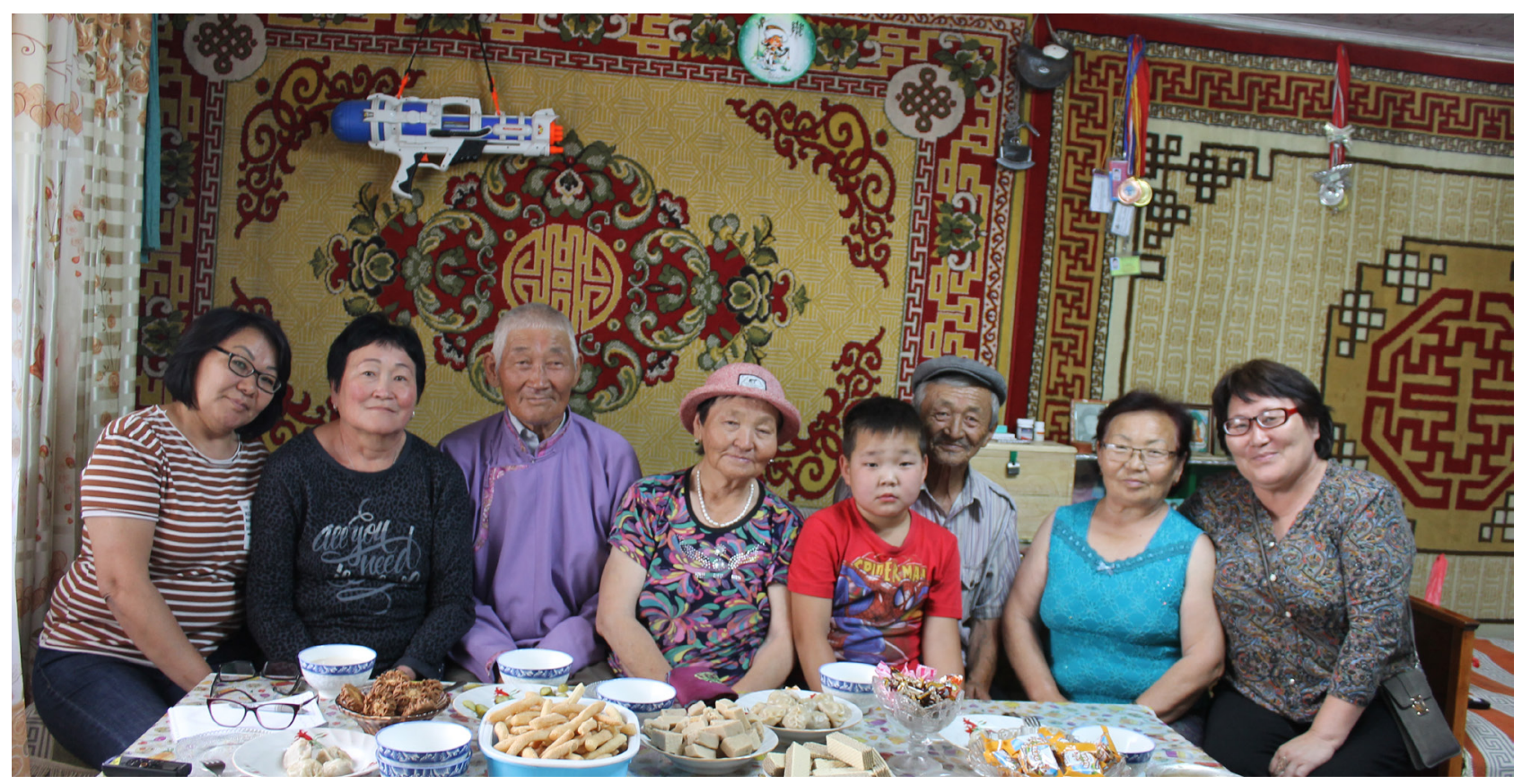

Фото 2. С информантами в сумоне Буянт Ховдского аймака Монголии в 2019 г. Фото из архива Н. Д. Сувандии. Photo 2. Working with respondents in sum Buyant, Khovd aimag, Mongolia, 2019.

Photo from the personal archive of N. D. Suvandii.

\footnotetext{
${ }^{1}$ Шунгуур Иргит Жамбаа оглу Баярхуу, 62 г., род. в мест. Харааты, Баян-Улэгэйского аймака Монголии.

${ }^{2}$ Моол Иргит Сериндорж, 78 л., род. в мест. Харааты, Баян-Улэгэйского аймака Монголии.

${ }^{3}$ Шунгуур Иргит Чимеддорж оглу Ганзориг, 34 г., род. в сумоне Цэнгэл, Баян-Улэгэйского аймака Монголии.

${ }^{4}$ Шунгуур Иргит Баярхуу уруу Болормаа, 26 лет, род. в сумоне Цэнгэл, Баян-Улэгэйского аймака Монголии.
} 
Этнические тувинцы сумона Буянт и г. Ховд Ховдского и сумона Цагаан-Нуур Хубсугульского аймаков, по сравнению с жителями Цэнгэла, редко используют в быту тувинские собственные имена, ими пользуется только часть старшего поколения. Молодежь и дети свой родной тувинский язык почти не знают, а люди среднего возраста понимают тувинскую речь, но не говорят. Следовательно, во время научной экспедиции нами зафиксировано небольшое количество материала по собственным именам.

По сведениям информаторов, на территории Ховдского аймака у этнических тувинцев в качестве так называемых «домашних имен» употребляются только в некоторых случаях исконно тувинские имена:

Саазын-Кулак /м./ - от слов саазын - ‘бумага’ и кулак - ‘ухо’, букв. ‘бумажное ухо’, дано носителю с оттопыренными, тонкими ушами;

Tac/ж./ - от тас - ‘лысый’, букв. ‘с лысой головой' ' ‘омашнее имя’ дано женщине, которая постоянно носит платок из-за редких волос на голове.

Дүкпенек /ж./ - от слова дүкпенек (ховдский диалект. - далее ховд.) каңмыыл (литературный тувинский язык. - далее лит. тув.) - ‘перекати-поле’, букв. ‘легкая, небольшая, как трава': имя дано худенькой по телосложению девушке;

Бүрүшкек /м./ - от бүрүшкек (ховд, лит. тув.) - ‘морщинистый; покоробленный’ (Тувинско-русский ..., 1968: 195), букв. 'морщинистый’: носитель всегда ходит со сморщенным лицом.

Көгерең /м./ - от көк - 'синий', дано носителю с синеватым и бледным оттенком кожи;

Морзук /м./ - от морзук /ховд., лит/ - ‘барсук’, прозвище дано носителю с полным, круглым телосложением.

Описанные личные имена встречаются у этнических тувинцев старшего поколения, в настоящее время подобными именами родители своих детей не нарекают.

У этнических тувинцев сумона Цагаан-Нуур нами собраны единичные «домашние имена», к которым относятся Чыргал /м./ - от слова чыргал 'блаженство, благоденствие; счастье' - имя 75-летнего дедушки; Өлчей /ж./ - от слова өлчей - 'счастье, благодать', «домашнее имя» бабушки, которой 80 лет (она с гордостью говорила, что в ее детстве их родители в быту употребляли тувинские имена ${ }^{1}$ ).

В настоящее время у молодежи и детей встречаются такие «домашние имена», имеющие параллели в тувинском языке: Шыыракпан /ж./ - от слова шыырак - 'сильный', имя парня-оленевода, который принимает участие в состязаниях по национальной борьбе в наадымах - праздниках животноводов; Багай-Уруг /м./ - от слов багай - 'плохой’ и уруг - 'девочка, девушка', охранное «домашнее имя» дано сыну оленеводов, в семье которых много дочерей, а мальчики умирали в младенчестве, живым остался один. Зафиксированы некоторые «домашние имена», которые у тувинцев Республики Тыва которые являются антропонимами, употребляющимися с древности по настоящее время: Kapa-оол /м./ - от слов кара - 'черный’ и оол - 'мальчик', имя, связанное с внешностью денотата; Биче-оол /м./ - от биче ‘маленький’ и оол 'мальчик' - имя самого младшего ребенка семьи оленеводов.

Таким образом, следует отметить, что этнические тувинцы сумона Цэнгэл Баян-Улэгэйского аймака Монголии больше используют в собственные имена в повседневной жизни по сравнению с тувинцами Ховдского и Хубсугульского аймаков, где подобные имена встречаются редко.

\section{Собственные имена - топонимы}

В сумоне Цагаан-Нуур Хубсугульского аймака Монголии этнические тувинцы занимаются в основном оленеводством и проживают в таежных местностях. Но исключение составляют семьи, проживающие недалеко от сумона и занимающиеся разведением так называемого «монгольского скота», к которым относят коров, овец, коз.

У этнических тувинцев старшего и среднего поколения данной территории в речи встречаются собственные имена исконно тувинского происхождения.

Нами зафиксированы следующие топонимы: Ак-Хөл (цагаан-нуурский диалект - далее ц.-н., лит. тув.) Цагаан-Нуур (монгольский - далее монг.) - от $а к$ - ‘белый’ и хөл - 'озеро', название озера, у которого построен сумон;

\footnotetext{
${ }^{1}$ Цегвээ Бунцул, 80 л., род. в Западной тайге Хубсугульского аймака Монголии.
} 
Чөөн-Тайга (ц.-н., лит. тув.) - от чөөн - ‘восточный’ и тайга - ‘тайга', местность, в которой проживают в основном оленеводы, перекочевавшие из Тере-Хольского района;

Барыын-Тайга (ц.-н., лит. тув.) - от барыын - 'западный’ и тайга - 'тайга', местность, в которой проживают в основном оленеводы, перекочевавшие из Тоджинского района;

Чараш-Даш (ц.-н., лит. тув.) - от чараш - ‘красивый’ и даш - ‘камень', местность, находящаяся недалеко от сумона, где обитают тувинцы с «монгольским» мелким и крупным рогатым скотом ${ }^{1}$;

Сайлыг (ц.-н., лит тув.) - от сайлыг - ‘имеющий гальку’, местность, находящаяся возле озера, где летом купается местная детвора;

Тытmыг-Ой (ц.-н.) Дыттыг-Ой (лит. тув) - от тыттыг дыттыг -‘имеющий лиственницу’ и ой 'лощина', местность в Восточной тайге.

Кертиктиг (и.-н., лит. тув) - от кертиктиг - ‘с зарубкой’ - таежная горная местность, где обитают в зимнее время оленеводы Западной тайги.

В сумоне Цагаан-Нуур Хубсугульского аймака Монголии больше всего нами зафиксированы географические наименования, которые встречаются параллели и на территории Республики Тыва:

Aк-Кем (цэнгэльский диалект - далее цэнг.) Ак-Хем (лит. тув.) - от слов ак - ‘белый’ и хем - 'река', букв. ‘белая река’: название рек в Барун-Хемчикском, Чаа-Хольском, Эрзинском районах Тувы, также реки в сумоне Цэнгэл Баян-Улэгэйского аймака Монголии. Название дано рекам, протекающим в открытых, безлесных местностях, также в глубине имеющим маленькие белые камушки (Ондар, 2007: 97);

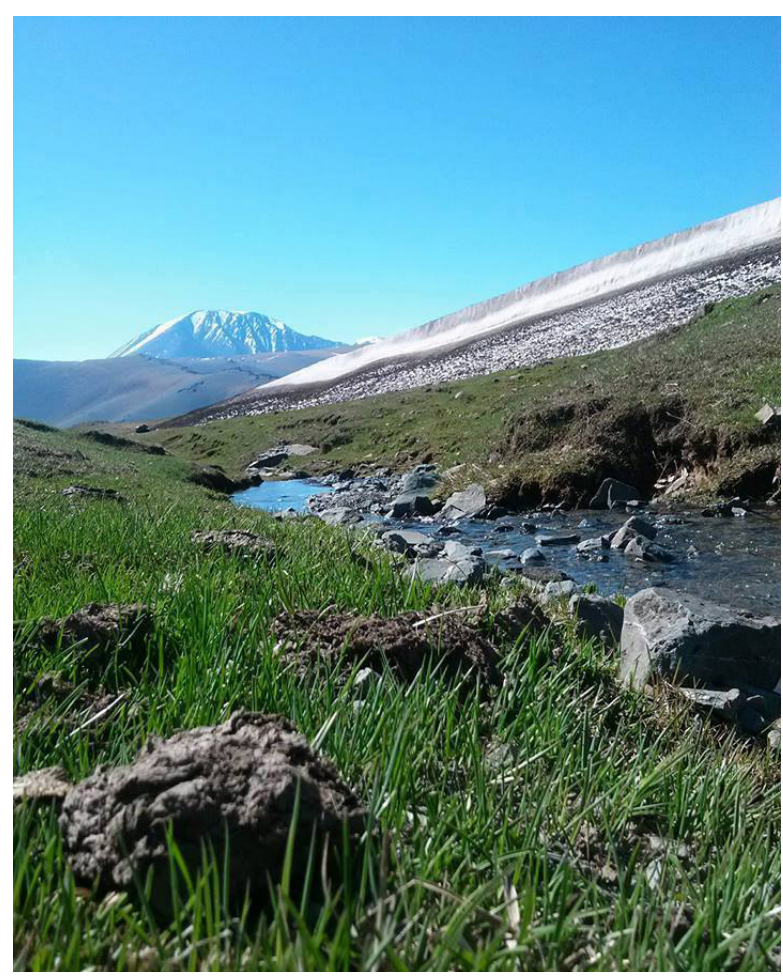

Фото 3. Местечко Узун-Ой в сумоне Цэнгэл Баян-Улэгэйского аймака Монголии в 2019 г. Фото из архива Н. Д. Сувандии.

Photo 3. Settlement Uzun Oi in sum Tsengel, Bayan-Ölgii aimag, Mongolia, 2019.

Photo from the personal archive of N.D. Suvandii.
$A \kappa-$ Кову (цэнг.) Aк-Хову (лит. тув.) - от $a \kappa-$ ‘белый’ и хову - ‘поле, степь' букв. ‘белое поле, белая степь’ название открытых степей на территории сумона Цэнгэл Монголии, также открытые степи в местечке Мунгаш-Ак Барун-Хемчикского района Тувы;

Хара-Бел (цэнг.) - от хара кара - ‘черный’ и бел 'склон горы', букв. 'черный склон горы': название местности, где хоронят умерших людей (кладбище) в сумоне Цэнгэл.

Хара-Хөл (цэнг.) Кара-Хөл (лит. тув.) - от кара 'черный' и бел 'склон горы', букв. 'черное озеро': название озера в местечке Харааты Цэнгэльского аймака и название озер в Монгун-Тайгинском, БайТайгинском, Тождинском, Эрзинском, Тандынском районах Тувы (там же: 243).

Отсюда следует отметить, что топонимов, связанных с цветовыми характеристиками, а именно со словами $а к$ - ‘белый’ и кара - ‘черный’ в исследуемых территориях встречается немало, притом они характеризуют внешние особенности местности.

Узун-Ой (цэнг., лит. тув.) - от слов узун - 'длинный' и ой - 'лощина', букв. 'длинная лощина': название рек в сумоне Цэнгэл Монголии, река в Тоджинском и Тес-Хемском районах Тувы (там же: 402).

Особо следует отметить топонимы, связанные с названиями животного мира, в частности домашних животных и птиц:

Кускуннуг (цэнг. лит) - от кускун - ‘ворон’. В сумоне Цэнгэл, по данным информаторов, это местность, где обитают птицы семейства вороновых. На территории Тувы Кускуннуг - это местность в урочище реки Каа-Хем, названа по логу, изобилующему воронами (там же: 276);

1 Чулууны Оюунбадам, 45 л., род. в сумоне Цагаан-Нуур Хубсугульского аймака Монголии. 


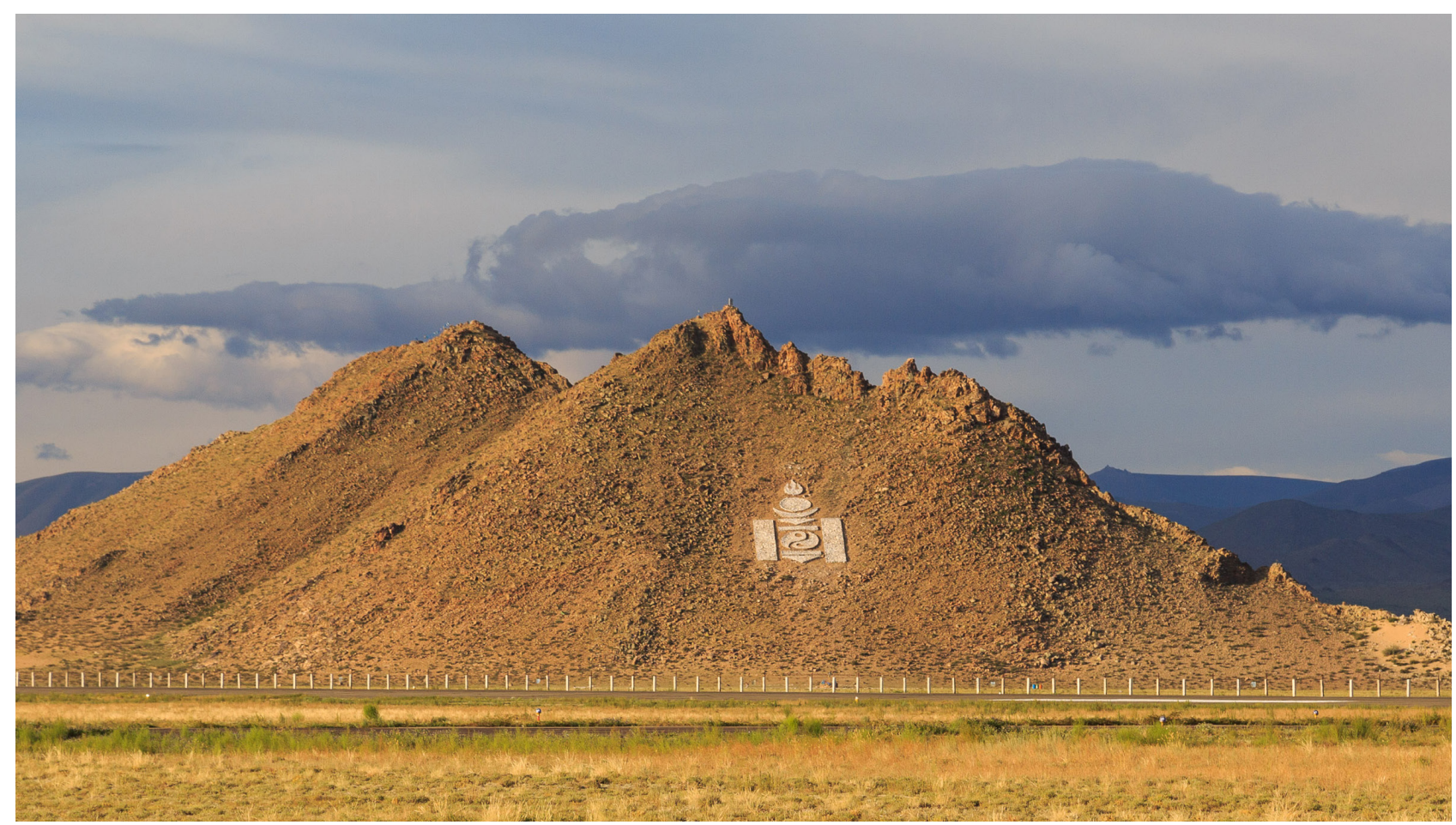

Фото 4. Священная гора Баатыр-Хайырхан в Ховдском аймаке Монголии, 2004 г. Фото из архива Цецегдарь Уламсурэн.

Photo 4. The sacred mountain of Baatyr-Hayyrkhan in Khovd aimag, Mongolia, 2004. Photo from the archive of Tsetsegdar Ulamsuren.

Чыланныг-Хем (цэнг., лит.) - от чыланныг - 'змеиный’ и хем - 'река', букв. 'змеиная река': весенняя стоянка у небольшой реки, в окрестностях которого обитают много змей;

Үс-Чуглур (цэнг.) - от $ү с$ - ‘масло толеное масло’ и чуглур - 'катиться, скатиться’, букв. 'скатилось топленое масло': во время перекочевки на волах с крутой горы, на которую поднялись, как рассказывал нам один информант, скатилось топленое масло, собранное за лето в брюшине домашнего скота ${ }^{1}$;

Улуг-Хая (цэнг., лит. тув.) - от улуг - ‘большой’ и хая - 'скала': местность с большими черными скалами в зимних стойбищах сумона Цэнгэл Монголии, местности в Бай-Тайгинском, Улуг-Хемском, Чаа-Хольском и Тоджинском районах Тувы (там же: 415);

Шыргай-Чүрек (цэнг.) - от шыргай - 'густой, дремучий’ и чүрек - 'сердце’, букв. 'густое сердце’: большая открытая местность, похожая с виду на сердце;

Кодан-Хөл (цэнг.) - от кодан койгун - 'заяц' и хөл - 'озеро', букв. 'заячье озеро’: небольшое озеро, вблизи которого обитают зайцы.

У этнических тувинцев сумона Буянт и г. Ховд к названиям географических объектов относятся следующие наименования:

Баатыр-Хайырхан (ховд.) - от слов баатар (монг.) маадыр (лит. тув.) -'герой’ и хайырхан (ховд.) хайрхан (монг.) хайыракан (лит. тув.) - '1. уст. рел. почтительное название божества; 2. медведь, медвежий’ - название священной горы на территории г. Ховд²;

Буянты (ховд.) - от слова буянт буянтай /монг./ 'добродетельный, благодетельный (Монгольскорусский ..., 1957: 92)' буян /тув./ - 'милость, доброта, сердечность; добро, благо' (Тувинско-русский ... , 1968: 125): название сумона, где проживают этнические тувинцы Ховдского аймака Монголии;

Жыргаланды (ховд.) - от слова жаргалант (монг.) жыргаланды /ховд/ - 'счастливый, благоженствующий, радостный’ (Монгольско-русский ..., 1957: 177) чыргалаң (лит. тув.) - ‘блаженство' (Тувинско-русский ..., 1968: 558): название священной горы на территории г. Ховд;

${ }^{1}$ Шунгуур Иргит Жамбаа оглу Баярхуу, 62 г., род. в мест. Харааты, Баян-Улэгэйского аймака Монголии.

${ }^{2}$ Бямбажав Цагаанбилэг, 31 г. род. в г. Ховд, Ховдинского аймака Монголии. 


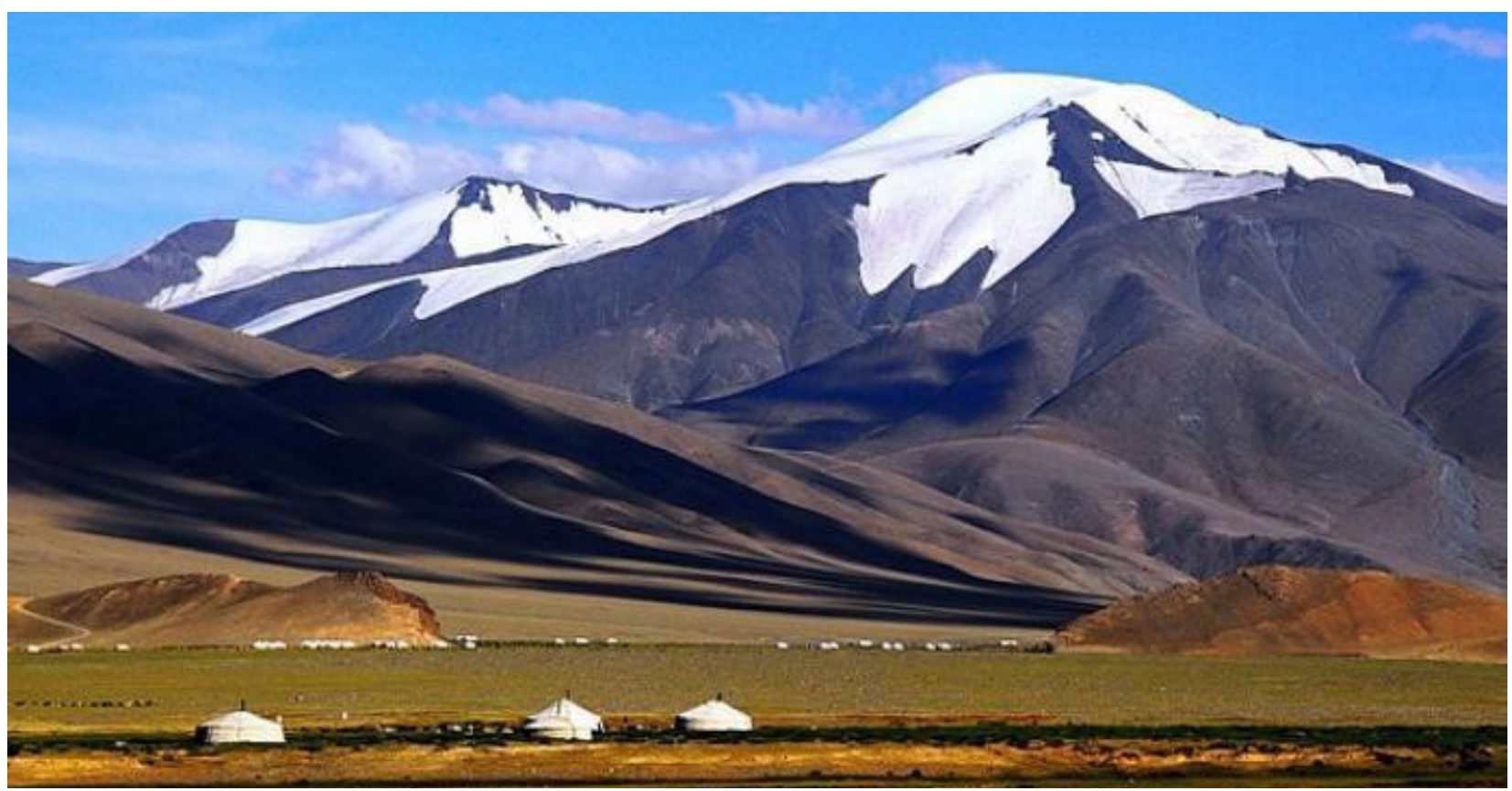

Фото 5. Священная гора Жыргаланды в Ховдском аймаке Монголии, 2005. Фото из архива Цецегдарь Уламсурэн.

Photo 5. The sacred mountain of Zhyrgalandy in Khovd aimag, Mongolia, 2005. Photo from the archive of Tsetsegdar Ulamsuren.

Кызыл-Хаак (ховд., лит. тув.) - от кызыл - 'красный’ и хаак - 'мелкий тальник; прут, лоза; розга' зимнее стойбище в сумоне Буянт, где растет множество мелких тальников красно-желтого цвета;

Сарыг-Хаак (ховд., лит. тув.) - от сарыг - 'желтый’ и хаак - 'мелкий тальник; прут, лоза; розга' весеннее стойбище в сумоне Буянт, где растет множество мелких тальников и различных цветов желтого цвета ${ }^{1}$;

Кара-Ус-Нуур (ховд.) - от кара (ховд., лит. тув.) - ‘черный’, ус (монг.) - ‘вода’ и нуур (монг.) - 'озеро’, букв. 'озеро с черной водой’': название озера, находящегося недалеко от г. Ховд;

Беш-Хайырхан (ховд.) - от беш - 'пять' и хайырхан (ховд.) хайрхан (монг.) хайыракан (тув.) '1. уст. рел. почтительное название божества; 2. медведь, медвежий’: название священной горы в сумоне Буянты;

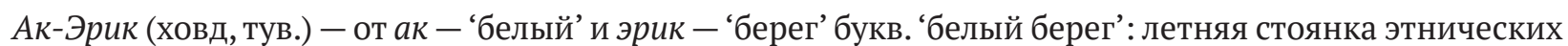
тувинцев сумона Буянды;

Көк-Серх Көк-Серге (ховд) - от слов көк (ховд., лит.) - 'синий’ и серх (монг.) - 'кастрированный козел’ (Монгольско-русский ..., 1957: 377) и серге (лит. тув.) - ‘козел’, букв. 'синий кастрированный козел': название священной горы синего цвета;

Чиңге-Хем (ховд.) - от чиңге 'узкий’ и хем - 'река', букв. 'узкая речка': приток реки Буянты, на берегу которого находятся летние стойбища этнических тувинцев.

Изучив использование топонимов исконно тувинского происхождения у тувинцев Ховдского аймака Монголии, мы пришли к выводу, что на данной территории в основном встречаются топонимы монгольского происхождения. А исконно тувинские, по мнению информаторов, почти уходят из употребления вместе с этническими тувинцами старшего поколения.

\section{Собственные имена - зоонимы}

Зоонимы - это собственные имена, присваиваемые в основном домашним животным. Поскольку тувинцы-животноводы тесно общались с домашними животными, то присваивали имена - клички почти всем или многим.

${ }^{1}$ Донгак Намзыра, 69 л., род. в мест. Ужук сумона Буянт, Ховдинского аймака Монголии. 
По сведениям наших информаторов сумона Цэнгэл, самую большую группу зоонимов составляют такие, которые указывают на внешние особенности: Калчапай - от калчан - ‘лысый, плешивый', кличка коров и овец; Биче-Калчан - от биче - 'маленький, меньший’ и калчан - ‘плешивый', букв. 'меньший плешивый’, так именуют младшую по возрасту корову среди одинаковых мастью; Саңмайлыг - от саңмай чирбеш - 'челка', кличка коровы, у которой ниспадающие волосы на лбу; Солчур-Мыйыс - от солчур солуур - 'обмениваться' и мыйыс - 'рога', букв. 'корова, у которой рога обмениваются местами' (у таких коров рога повернуты друг к другу, могут образовывать дугу, называются встречными уткушкак); Салдыгбай - от салдыг - 'с усами', кличка козы, имеющей волосы как усы; Кош-Кулак - от кош - ‘парный, двойной’ и кулак - 'ухо’, букв. с 'парными ушами’, кличка овцы, у которой есть дефект ушей, Шумаш - от шумаш (синоним сочетания кулак чок - 'не имеющий уха'), кличка мелкого рогатого скота, родившегося с маленькими ушками. С подобными кличками овцы имеются и на территории Тувы.

Следующую группу составляют зоонимы, указывающие на различные цвета (масти) животных, например, Көгүлдей - от слова көк - 'синий', букв. 'синенький’, корова синеватого цвета; Аладай, Алапай - от ала - 'пегий’, кличка животного по масти: коровы, лошади, овцы, козы; Шоокар Шокар от шокар - 'пестрый, рябой, пятнистый', такие клички дают в основном крупному рогатому скоту (лошадям, коровам, якам) ${ }^{1}$; Чыраа-Доруг - от чыраа - ‘иноходец’ и доруг - 'гнедой’, кличка лошади по масти; Ала-Калдар - от ала - 'пегий’ и калдар - 'мухортый’, кличка, указывающая на особую масть любимого коня² и т. д.

На территории сумона Цэнгэл зафиксировано немало зоонимов, связанных с различными аллюрами лошадей: Чожаң /цэнг/ - от чоржаң - ‘ленивый, медлительный'; Чыраапай - от чыраа - ‘иноходец'; Челер-Ой - от челер - ‘идти рысью’ и ой - ‘буланый’ Чұгұрүкей - от чүгүрүк - ‘быстрый’ и др.

В отличие от этнических тувинцев Западной Монголии цаатаны, помимо лошадей, дают клички и оленям, например, Куу-Дай - от куу - 'серый, бледный’ и дай - 'жеребенок', такой бывает кличка сероватого оленя; Духур-Миис - от духур дугур - ‘короткий’ и миис мыйыс - 'рога', это кличка оленя с коротко стриженными рогами; Чаңгыс-Миис - от чаңгыс - 'один' и мыйыс - 'рога', кличка оленя, у которого одни рога с рождения, Хоптаанай - от слова хоптак - ‘прожорливый, жадный, алчный’, кличка оленя, который постоянно что-то жует (кусок ткани, кожура картошки) и т. д.

\section{Заключение}

Этнические тувинцы Монголии, так же, как и тувинцы Республики Тыва, используют в повседневной жизни немало собственных имен исконно тувинского происхождения. Но из всех трех исследованных территорий этнические тувинцы сумона Цэнгэл отличаются тем, что их жители остались наиболее сохранившими язык и культуры своих предков. Свидетельством данного явления является тот факт, что большая часть собранных нами собственных имен зафиксирована в Баян-Улэгэйском аймаке.

Наибольшее количество из всех собственных имен во всех рассмотренных аймаках Монголии составляют топонимы, имеющие такие же параллельные наименования и на территории Республики Тыва, например, $A$-Кову (цэнг.) Aк-Хову (лит. тув.) - от ак ‘белый’ и хову ‘поле, степь’ букв. ‘белое поле, белая степь': название открытых степей на территории сумона Цэнгэл Монголии, также открытые степи в местечке Мунгаш-Ак Барун-Хемчикского района Тувы и др.

У этнических тувинцев Баян-Улэгэйского аймака, помимо официальных монгольских имен, имеются кош аттар - 'парные имена'. Имеются также единичные өг аттары - 'домашние имена' (прежде всего у ховдских тувинцев), в сумоне Цагаан-Нуур также они встречаются, но очень редко.

В сумоне Цэнгэл Баян-Улэгэйского и Буянт Ховдского аймаков этнические тувинцы занимаются разведением крупного и мелкого рогатого скота, а тувинцы Цагаан-Нуура - оленеводством. Все эти хозяйственные особенности отражаются на наличии и составе зоонимов.

\footnotetext{
${ }^{1}$ Шунгуур Иргит Жамбаа уруу Оюун, 50 л., род. в сумоне Цэнгэл, Баян-Улэгэйского аймака Монголии.

${ }^{2}$ Адай-Иргит Багбаяр, 30 л., род. в сумоне Цэнгэл, Баян-Улэгэйского аймака Монголии.
} 


\section{СПИСОК ЛИТЕРАТУРЫ}

Бавуу-Сюрюн, М. В. (2018) Топонимы как маркеры диалектов и говоров тувинского языка // Новые исследования Тувы. № 3. С. 18-32. https://www.doi.org/10.25178/nit.2018.3.2

Бадарч, Б. (2009) Лексика животноводства в цэнгэльском диалекте тувинского языка: в сравнительно-сопоставительном аспекте : дисс.... к. филол. н. Новосибирск. 190 с.

Бадарч, Б., Бавуу-Сюрюн, М. В. (2018) Монголизмы в тувинских топонимах: сопоставительный анализ географических названий сумона Цэнгэ Баян-Улэгэйского аймака Монголии // Новые исследования Тувы. № 3. C. 215-224. DOI: https://doi.org/10.25178/nit.2018.3.14

Бондалетов, В. Д. (2016) Русская ономастика. М. : Книжный дом «Либроком». 310 с.

Вайнштейн, С. И. (1969) Личные имена, термины родства и прозвища у тувинцев // Ономастика / отв. ред. В. А. Никонов, А. В. Суперанская. М. : Наука. 261 с. С. 125-132.

Вайнштейн, С. И. (1989) Тувинцы // Системы личных имен у народов мира / отв. ред. М. В. Крюков. М. : Наука. 382 с. С. 305-307.

Кара-оол, Л. С. (2018) Лексические особенности топонимов Овюрского района Тувы // Новые исследования Тувы. № 3. С. 162-189. DOI: https://doi.org/10.25178/nit.2018.3.11

Кара-оол, Л. С. (2019а) Лексика родильных обрядов в топонимах Тувы // Мир науки, культуры, образования. № 3. С. 368-369.

Кара-оол, Л. С. (2019b) Числительные в топонимах Тувы // Oriental Studies. № 4. C. 691-706. DOI: 10.22162/26190990-2019-44-4-691-706.

Катанов, Н. Ф. (1903) Опытъ изслъдованія урянхайскаго языка, съ указаніемъ главнъйшихъ родственныхъ отношеній его къ другимъ языкамъ тюркскаго корня. Казань : Типо-литографія Императорскаго Казанскаго Университета. 1600 с.

Монгольско-русский словарь (1957) / отв. ред. А. Лувсандэнэв. М.: Государственное издательство иностранных и национальных словарей. 715 с.

Монгуш, Б. М., Юлдашбаев, Ю. А. (2015) Некоторые основные масти и отметины тувинских лошадей спортивного направления // Вестник Тувинского государственного университета. Вып. 2. Естественные и сельскохозяйственные науки. С. 145-150.

Ондар, Б. К. (2004) Топонимический словарь Тувы. Абакан : Изд-во ХГУ им. Н. Ф. Катанова. 254 с.

Ондар, Б.К. (2007) Топонимический словарь Тувы. 2-е изд. Кызыл : Тувинское книжное издательство. 550 с.

Ондар, Б. К. (2008) Тувинская топонимия. Сопоставительный анализ топонимии Тувы с топонимами Южной Сибири и других тюркоязычных территорий. Кызыл : Тувинское книжное изд-во. 296 с.

Ондар, Б. К. (2011) Русская топонимия Тувы. Кызыл : Редакционно-издательский отдел ТувГУ. 168 с.

Сат, Ш. Ч. (1969) Заметки по топонимике Тувы // Материалы конференции «Этногенез народов Северной Азии» / отв. ред. Е. И. Убрятова. Новосибирск : Сиб. Отд-ние АН СССР. Институт истории, филологии, философии. 247 c. С. $232-234$.

Сувандии, Н. Д. (2011) Тувинская антропонимия. Кызыл : Редакционно-издательский отдел ТувГУ. 207 с .

Сувандии, Н. Д. (2012) Тувинские личные имена монгольско-тибетского происхождения // Сибирский филологический сборник. № 1. С. 111-116.

Сувандии, Н. Д. (2016) Особенности собственных имен усинских тувинцев // Филологические науки. Вопросы теории и практики. № 12. С. 163-165.

Сувандии, Н. Д. (2018) Вклад Бичен Кыргысовны Ондар в развитие топонимики Тувы // Новые исследования Тувы. № 3. С. 4-17. DOI: https://doi.org/10.25178/nit.2018.3.1

Сувандии, Н. Д. (2019а) Топонимы-цветообозначения в тувинском языке // Новые исследования Тувы. № 4. C. 195-206. DOI: https://doi.org/10.25178/nit.2019.4.16

Сувандии, Н. Д. (2019b) Официальные и «вторые» имена этнических тувинцев Монголии Тувы // Oriental Studies. № 44 (4) С. 661-668. DOI: https://doi.org/10.22162/2619-0990-2019-44-4-661-668

Сувандии, Н. Д. (2020) Способы образования простых личных имен тувинцев // Новые исследования Тувы. № 1. C. 88-95. DOI: https://doi.org/10.25178/nit.2020.1.7

Сувандии, Н. Д., Куулар, Е. М. (2010) Особенности употребления зоонимов у оленеводов-тоджинцев // Кочевые цивилизации народов Центральной и Северной Азии: история, состояние, проблемы. Сборник материалов II Международной научно-практической конференции / отв. ред. Н. Н. Дроздов. Кызыл ; Красноярск : Ред.-изд. отдел КГПУ. 358 с. С. 268-271.

Татаринцев, Б. И. (1973) Об особенностях топонимии Северо-Восточной Тувы // Происхождение аборигенов Сибири и их языков / отв. ред. А. П. Дульзон. Томск : Изд-во Томского университета. 235 с. С. 142-144.

Татаринцев, Б. И. (1977а) Местные географические термины Северо-Восточной Тувы // Советская тюркология Вып. 5. С. 18-26. 
Татаринцев, Б. И. (1977b) О топонимии бассейна реки Каа-Хем // Тувинский язык и литература в послеоктябрьский период / отв. ред. Д. А. Монгуш. Кызыл : Тип-ия управления по делам издательств, полиграфии и книжной торговли Совета Министров Тув. АССР. 187 с. С. 88-99.

Тувинско-русский словарь (1968): 22000 слов / ред. Э. Р. Тенишев. М. : Советская энциклопедия. 648 с.

Уламсурэн, Ц. (2013) Особенности тувинской речи жителей Кобдо : дисс. ... к. филол. н. М. 174 с.

Хийс, Г. (2009) Особенности тувинской речи жителей Цэнгэла : дисс. ... к. филол. н. Новосибирск. 190 с.

Чадамба, 3. Б. (1965) Тувинские имена // Справочник личных имен народов РСФСР / отв. ред. Н. А. Баскаков и др. М. : Советская энциклопедия 253 с. С. 174-177.

Чадамба, 3. Б. (1993) Способы образования тувинских личных имен // Вопросы тувинского языкознания / отв. ред. Д. А. Монгуш, Б. И. Татаринцев. Кызыл : МП «Новости Тувы». 126 с. С. 98-105.

Дата поступления: 19.09.2020 г.

\section{REFERENCES}

Bavuu-Surun, M. V. (2018) Toponimy kak markery dialektov i govorov tuvinskogo iazyka [Place names as markers of the dialects and sub-dialects of Tuvan language]. The New Research of Tuva, no. 3, pp. 18-32. (In Russ.). DOI: https://www. doi.org/10.25178/nit.2018.3.2

Badarch, B. (2009) Leksika zhivotnovodstva $v$ tsengel'skom dialekte tuvinskogo iazyka: $v$ sranitel'no-sopostavitel'nom aspekte [Vocabulary of animal husbandry in the Tsengel dialect of the Tuvan language: a comparative aspect]: Diss. ... Candidate of Philology. Novosibirsk. 190 p. (In Russ.).

Badarch, B. and Bavuu-Surun, M. V. (2018) Mongolizmy v tuvinskikh toponimakh: sopostavitel'nyi analiz geograficheskikh nazvanii sumona Tsenge Baian-Ulegeiskogo aimaka Mongolii [Mongolisms in Tuvan toponyms: a comparative analysis of place names in Tsengel sum of Bayan-Olgii aimag, Mongolia with those of Tuva]. New Research of Tuva, no. 3, pp. 215-224. (In Russ.). DOI: https://doi.org/10.25178/nit.2018.3.14

Bondaletov, V. D. (2016) Russkaia onomastika [Russian onomastics]. Moscow, Librokom. 310 p. (In Russ.).

Weinstein, S. I. (1969) Lichnye imena, terminy rodstva i prozvishcha u tuvintsev [Personal names, kinship terms and nicknames among Tuvans]. In: Onomastika [Onomastics] / ed. by V. A. Nikonov and A. V. Superanskaia. Moscow, Nauka. 261 p. Pp. 125-132. (In Russ.).

Weinstein, S. I. (1989) Tuvintsy [Tuvans]. In: Sistemy lichnykh imen u narodov mira [Systems of personal names among the peoples of the world] / ed. by M. V. Kriukov. Moscow, Nauka. 382 p. Pp. 305-307. (In Russ.).

Kara-ool, L. S. (2018) Leksicheskie osobennosti toponimov Oviurskogo raiona Tuvy [Lexical features of microtoponyms of Ovyur rayon of Tuva]. New Research of Tuva, no. 3, pp. 162-189. (In Russ.). DOI: https://doi.org/10.25178/nit.2018.3.11

Kara-ool, L. S. (2019a) Leksika rodil'nykh obriadov v toponimakh Tuvy [Vocabulary of maternity rites in toponyms of Tuva]. Mir nauki, kul'tury, obrazovaniia, no. 3, pp. 368-369. (In Russ.).

Kara-ool, L. S. (2019b) Chislitel'nye v toponimakh Tuvy [Numerals in toponyms of Tuva]. Oriental Studies, no. 4 (44), pp. 691-706. (In Russ.). DOI: https://doi.org/10.22162/2619-0990-2019-44-4-691-706

Katanov, N. F. (1903) Opyt izsledovaniia uriankhaiskago iazyka, s ukazaniem glavneishikh rodstvennykh otnoshenii ego $k$ drugim iazykam tiurkskago kornia [An essay on the Uryanghai language, indicating the most important kinship ties between him and the other languages of the Turkic root]. St. Petersburg, Tipo-litografiia Imperatorskogo universiteta. 1600 p. (In Russ.).

Mongol'sko-russkii slovar' [Mongolian-Russian dictionary] (1957) / ed. by A. Luvsandenev. Moscow, Gosudarstvennoe izdatel'stvo inostrannykh i natsional'nykh slovarei. 715 p. (In Russ.).

Mongush B. M. and Yuldashbaev Yu. A. (2015) Nekotorye osnovnye masti i otmetiny tuvinskikh loshadei sportivnogo napravleniia [Some basic coat colors and markings of Tuvan sports horses]. Vestnik Tuvinskogo gosudarstvennogo universiteta. Vol. 2. Estestvennye i sel'skokhoziaistvennye nauki. Pp. 145-150.

Ondar, B. K. (2004) Toponimicheskii slovar' Tuvy [A toponymic dictionary of Tuva]. Abakan, Izd-vo Khakasskogo gosudarstvennogo universiteta im. N. F. Katanova. 256 p. (In Russ.).

Ondar, B. K. (2007) Toponimicheskii slovar' Tuvy [A toponymic dictionary of Tuva]. 2nd ed. Kyzyl, Tuvan book publisher. 550 p. (In Russ.).

Ondar, B. K. (2008) Tuvinskaia toponimiia. Sopostavitel'nyi analiz toponimii Tuvy s toponimami Iuzhnoi Sibiri i drugikh tiurkoiazychnykh territorii [Tuvan toponyms. A comparative analysis of toponyms of Tuva with those of southern Siberia and other Turkic-speaking territories]. Kyzyl, Tuvan book publisher. 296 p. (In Russ.).

Ondar, B. K. (2011) Russkaia toponimiia Tuvy [Russian placenames in Tuva]. Kyzyl, Redaktsionno-izdatel'skii otdel TuvGU. 168 p. (In Russ.).

Sat, Sh. Ch. (1969) Zametki po toponimike Tuvy [Notes on the toponyms of Tuva]. In: Materialy konferentsii «Etnogenez narodov Severnoi Azii» [Proceedings of the conference "Ethnogenesis of the peoples of North Asia"] / Ed. by E. I. Ubriatova. Novosibirsk, s. n. 247 p. Pp. 232-234. (In Russ.). 
Suvandii, N. D. (2011) Tuvinskaia antroponimiia [Tuvan anthroponymy]. Kyzyl, Editorial and Publishing Department of Tuvan State University Publishing house. 207 p. (In Russ.).

Suvandii, N. D. (2012) Tuvinskie lichnye imena mongol'sko-tibetskogo proiskhozhdeniia [Tuvinian personal names of mongolian and tibetan origin]. Sibirskii filologicheskii sbornik, no. 1, pp. 111-116. (In Russ.).

Suvandii, N. D. (2016) Osobennosti sobstvennykh imen usinskikh tuvintsev [The peculiarities of Usinsk Tuvinians' proper names]. Filologicheskie nauki. Voprosy teorii i praktiki, no. 12, pp. 163-165. (In Russ.).

Suvandii, N. D. (2018) Vklad Bichen Kyrgysovny Ondar v razvitie toponimiki Tuvy [Bichen Kyrgyzovna Ondar and her contribution to the study of the toponymy of Tuva]. New Research of Tuva, no. 3, pp. 4-17. (In Russ.). DOI: https://doi. org/10.25178/nit.2018.3.1

Suvandii, N. D. (2019a) Toponimy-tsvetooboznacheniia v tuvinskom iazyke [Place names of color designation in Tuvan language]. New Research of Tuva, no. 4, pp. 195-206. (In Russ.). DOI: https://doi.org/10.25178/nit.2019.4.16

Suvandii, N. D. (2019a) Ofitsial'nye i «vtorye» imena etnicheskikh tuvintsev Mongolii [Ethnic Tuvans of Mongolia: Official and 'Second' Names]. Oriental Studies, no. 4, pp. 661-668. (In Russ.). DOI: https://doi.org/10.22162/2619-09902019-44-4-661-668

Suvandii, N. D. (2020) Sposoby obrazovaniia prostykh lichnykh imen tuvintsev [Methods of formation of simple personal names in Tuvan]. New Research of Tuva, no. 1, pp. 88-95. (In Russ.). DOI: https://doi.org/10.25178/nit.2020.1.7

Suvandii, N. D. and Kuular E. M. (2010) Osobennosti upotrebleniia zoonimov u olenevodov-todzhintsev [Features of the use of zoonyms among Tozhu reindeer herders]. In: Kochevye tsivilizatsii narodov Tsentral'noi i Severnoi Azii: istoriia, sostoianie, problem [Nomadic civilizations of the peoples of Central and North Asia: history, state, problems]. Collection of materials of the 2nd International research and practical conference / ed. by N. N. Drozdov. Kyzyl, Krasnoiarsk, Red.izd. otdel KGPU. 358 p. Pp. 268-271. (In Russ.).

Tatarintsev, B. I. (1973) Ob osobennostiakh toponimii severo-vostochnoi Tuvy [About the peculiarities of toponyms of North-Eastern Tuva]. In: Proiskhozhdenie aborigenov Sibiri i ikh iazykov [The origin of aboriginal peoples of Siberia and their languages] : Proceedings of All-Union conference, June 14-16, 1973]. Tomsk, Tomskii un-t Publ. 236 p. Pp. $142-144$. (In Russ.).

Tatarintsev, B. I. (1977a) Mestnye geograficheskie terminy severo-vostochnoi Tuvy [Local geographical terms of NorthEastern Tuva]. In: Sovetskaia tiurkologiia [Soviet Turkology]. Vol. 5. / Ed. by M. Sh. Shiraliev. Baku, Tip-ia im. 26-ti bakinskikh komissarov. 112 p. Pp. 18-26. (In Russ.).

Tatarintsev, B. I. (1977b) O toponimii basseina r. Kaa-Khem [On the toponyms of the river Kaa-Khem]. In: Tuvinskii iazyk i literatura $v$ posleoktiabr'skii period [Tuvan language and literature in the post-October period] / Ed. by D. A. Mongush. Kyzyl, Tip-iia upravleniia po delam izdatel'stv, poligrafii i knizhnoi torgovli Soveta Ministrov Tuv. ASSR. 192 p. Pp. 88-99. (In Russ.).

Tuvinsko-russkii slovar' [A Tuvan-Russian Dictionary] (1968): c. 22000 words / ed. by E. R. Tenishev. Moscow, Sovetskaia entsiklopediia. 465 p. (In Russ. and Tuv.).

Ulamsuren, Ts. (2013) Osobennosti tuvinskoi rechi zhitelei Kobdo [Features of the Tuvan speech of the people of Kobdo]: Diss.... Candidate of Philology. Moscow. 174 p. (In Russ.).

Khiis, G. (2009) Osobennosti tuvinskoi rechi zhitelei Tsengela [Features of the Tuvan speech of people of Tsengel]: Diss.... Candidate of Philology. Novosibirsk. 190 p. (In Russ.).

Chadamba, Z. B. (1965) Tuvinskie imena [Tuvan names]. In: Spravochnik lichnykh imen narodov RSFSR [Directory of personal names of peoples of the RSFSR], ed. by N. A. Baskakov et al. Moscow, Sovetskaia entsiklopediia. 253 p. Pp. 174-177. (In Russ.).

Chadamba, Z. B. (1993) Sposoby obrazovaniia tuvinskikh lichnykh imen [Formation methods of the Tuvan personal names]. In: Voprosy tuvinskogo yazykoznaniya [Questions of Tuvan linguistics] / ed. by D. A. Mongush and B. I. Tatarincev. Kyzyl, Tuvinskii nauchno-issledovatel'skii institut yazyka, literatury i istorii. 128 p. Pp. 98-105. (In Russ.).

Submission date: 19.09.2020. 